\title{
First record of ostracods from the Upper Ordovician red-coloured marine sandstones of the Tierekeawati Formation in Tarim Basin, NW China: implications on palaeoenvironment and palaeobiogeography
}

\author{
Jun-Jun Song ${ }^{1,2^{*}}$, Yi-Xin Shen ${ }^{3^{*}}$, Peng Tang ${ }^{2,4}$, Xiao-Le Zhang ${ }^{2,4}$, Qi-Jian Li ${ }^{1,2}$ and Zheng-Jiang Luo ${ }^{5}$
}

\begin{abstract}
Ostracods are described for the first time from the red-coloured marine sandstones of Arisu section (Arisu red beds) of the Upper Ordovician Tierekeawati Formation in Kalpin area of northwestern Tarim Basin, Xinjiang Uygur Autonomous Region (Xinjiang), Northwest China. Twenty-two species belonging to thirteen genera are described and figured. The ostracod fauna suggests a probable Sandbian-Katian age for these beds. The palaeoecological assemblage of ostracod fauna implies the deposition in a nearshore-offshore environment during a regression when the Arisu red beds of the Tierekeawati Formation were laid down in the Tarim Basin. Many cosmopolitan and provincial genera were present in diversified ostracod fauna of the Arisu red beds, suggesting the possible biogeographic relationships among the Tarim, Tibet, and South China plates, as well as Europe and North America continents during the Late Ordovician. Ostracods experienced faunal exchanges between Laurentia and the Tarim Plate during the Late Ordovician Period.
\end{abstract}

Keywords: Ostracods, Late Ordovician, Arisu section, Tierekeawati Formation, Kalpin area, Tarim Basin, GOBE, STTS

\section{Introduction}

Ostracods are one of the most widespread and diverse group of crustaceans since the Early Ordovician and are still thriving today (Horne et al. 2002; Siveter 2008). After the origin of the clade, ostracods experienced critical turnover of composition in the Late Ordovician Period, which is also considered to be a key interval for the Great Ordovician Biodiversification Event (GOBE)

\footnotetext{
*Correspondence: jjsong@nigpas.ac.cn; jlyang@upc.edu.cn

'Nanjing Institute of Geology and Palaeontology, Chinese Academy of Sciences, Nanjing 210008, Jiangsu Province, China

${ }^{3}$ College of Geoscience and Technology, China University of Petroleum (East

China), Qingdao 266580, Shandong Province, China

Full list of author information is available at the end of the article
}

and the Paleozoic Evolutionary Fauna (Frey et al. 2004). Ordovician time was one of the favorable periods for ostracods, particularly in marine environments, from coastal sea to deep sea settings. They play an important role in stratigraphic subdivisions and consequently for biogeographic correlations (e.g., Swain 1957; Tinn and Meidla 2002; Mohibullah et al. 2011; Salas 2011; Taha 2018). Moreover, ostracods are one of the best fossils to reconstruct palaeoenvironment and palaeogeography of the Ordovician (e.g., Williams et al. 2003; Landing et al. 2013; Taha 2018; Zhang et al. 2018) due to their sensitivity to ambient factors such as oxygenation, salinity, bathymetry, temperature, hydrodynamics and nutrients. 


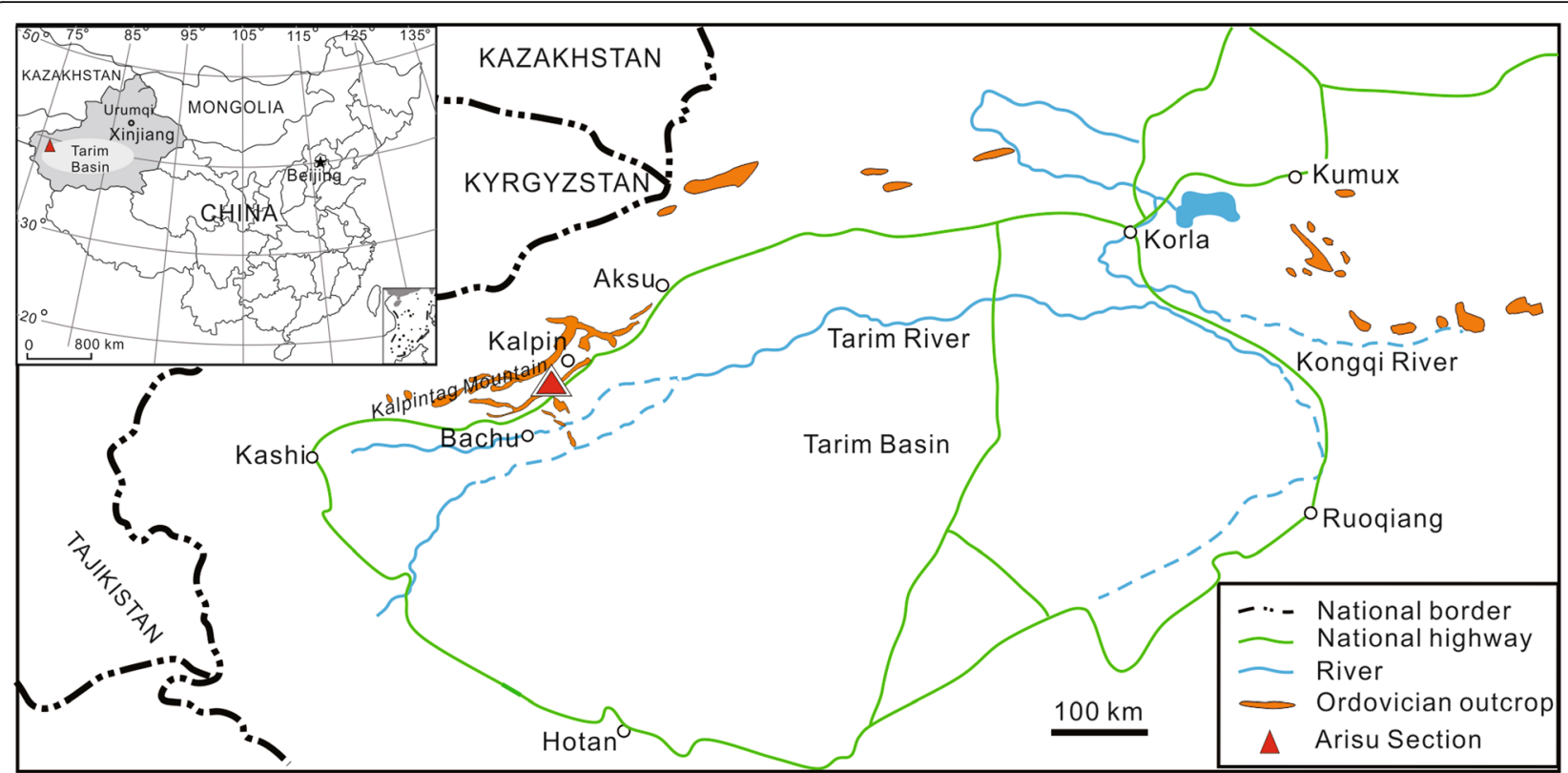

Fig. 1 Location of the Arisu section (marked by red triangle) in Kalpin area, northwestern Tarim Basin, Northwest China (the insert map of China is referring the standard map available on the official website of Ministry of Natural Resources of China: http://bzdt.ch.mnr.gov.cn/)

Ordovician strata are widely distributed and exposed in northwestern Tarim Basin, Northwest China, especially in the Arisu section in Kalpin area (Fig. 1), and its lithostratigraphy and biostratigraphy have been studied in detail (e.g., Zhou 2001; Wu 2003; Chen et al. 2012, 2013; Zhang and Munnecke 2016; Han et al. 2017). However, Ordovician ostracod successions of Kalpin area have so far been little known, except for ostracods from the Caradocian (Wu 2003). Recently we discovered ostracods in red-coloured marine siliciclastic sediments (referred to as Arisu red beds) from the lower part of the Upper Ordovician Tierekeawati Formation in Kalpin area (Fig. 2).

The goal of this paper is to report the ostracods occurring in these Arisu red beds of the Upper Ordovician Tierekeawati Formation in northwestern Tarim Basin, Xinjiang, Northwest China, and to discuss their biostratigraphical, palaeoecological and palaeogeographical implications.

\section{Geological setting and stratal section description}

Tarim Basin, the largest basin of China, is located in the south of Xinjiang, Northwest China (Fig. 1); the area is the location of the Taklamakan Desert, the largest desert of China. The tectonics, lithostratigraphy and biostratigraphy of Tarim Basin have been studied in detail for petroleum exploration (e.g., Qiao 1986; Zhou and Chen 1992; Jia et al. 2004; Wang et al. 2007; Zhen et al. 2011; $\mathrm{Li}$ et al. 2017). The Ordovician strata are widely distributed and exposed in northwestern and northeastern margins of the Tarim Basin, especially in the Kalpin area (Fig. 1). The Upper Ordovician sequence is usually subdivided into two lithostratigraphic units from the Katian to the Hirnantian Stages, i.e. the Yingan Formation and the Tierekeawati Formation (Huang et al. 2009; Chen et al. 2013; Zhang et al. 2019). The Yingan Formation is unconformably overlain by the Tierekeawati Formation in the Kalpin area (Fig. 2) as a result of the Kwangsian Orogeny (Huang et al. 2009; Chen et al. 2013), which elevated the Tarim Basin to form land from early to middle Katian time (Zhou et al. 1992). Lithology of the Yingan Formation varies from east to west in the Kalpin area. In the east, the Yingan Formation is composed mainly of dark grey carbonaceous, calcareous and silty shales, intercalated with a few calcilutites, and contains rich graptolites and chitinozoans in association with well-preserved small-sized trilobites and inarticulate brachiopods (Zhou et al. 1992). In the west, the Yingan Formation is composed of dark grey calcareous shales in the lower part, and thin- to thick-bedded nodular limestone, bioclastic limestone in the upper part (Zhao et al. 2000; Han et al. 2017; Fig. 2). The Tierekeawati Formation consists of greyish green argillaceous siltstone intercalated with thin- to thick-bedded sandstone. A few chitinozoans and acritarchs have been documented, and accordingly the Tierekeawati Formation was assigned to late Katian Stage, corresponding to the Dicellograptus complexus graptolite biozone (Huang et al. 2009; Tang et al. 2012; Chen et al. 2013; Zhang et al. 2019).

The Arisu section $\left(40^{\circ} 15^{\prime} 47.95^{\prime \prime} \mathrm{N}, 78^{\circ} 51^{\prime} 15.87^{\prime \prime} \mathrm{E}\right)$ is located in the north of the Kalpintag Mountain, about 


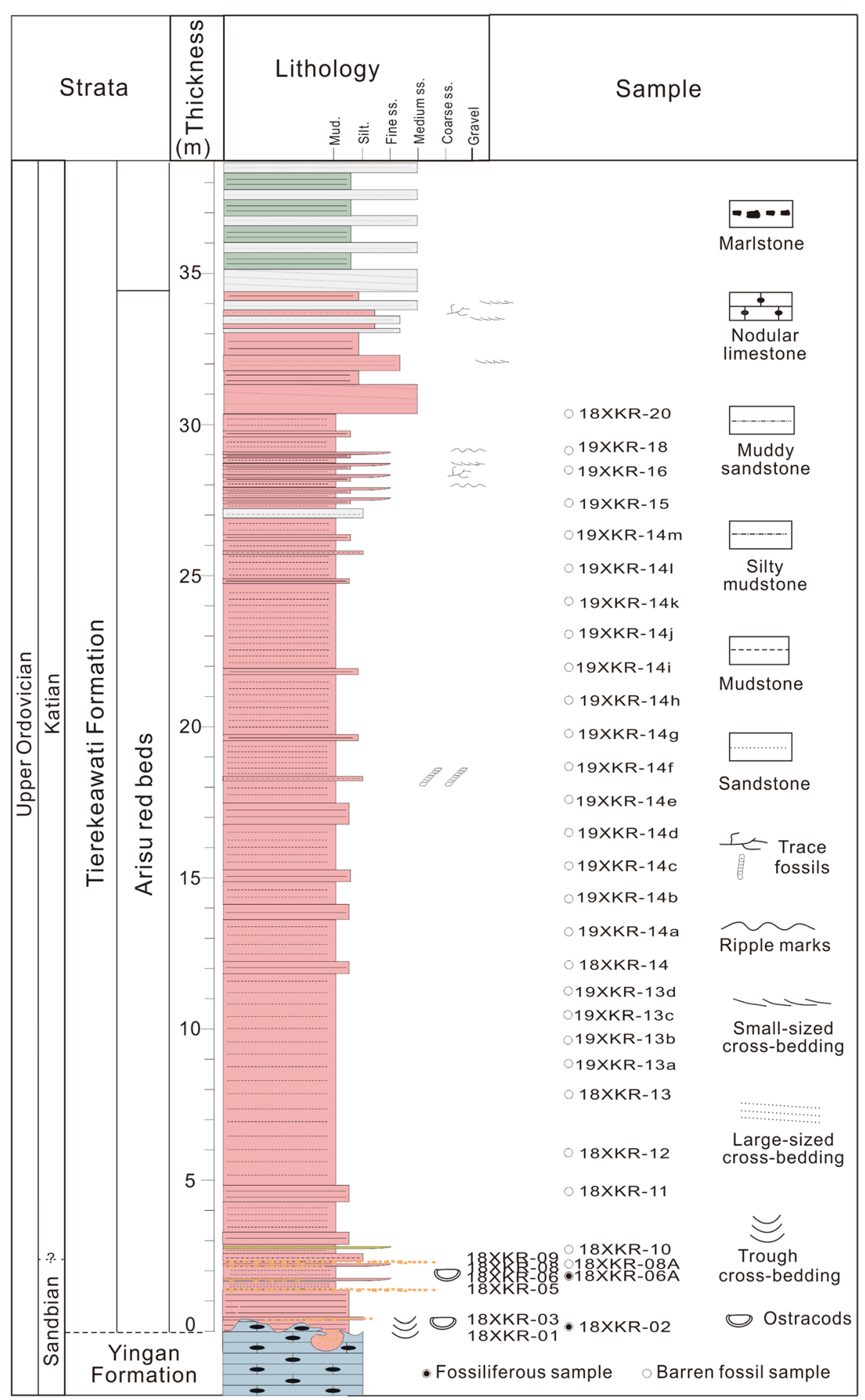

Fig. 2 Lithological column of the Tierekeawati Formation and samples collected from the Arisu red beds in Kalpin area, northwestern Tarim Basin, Northwest China. 18XKR- and 19XKR-number represent sample numbers, respectively sampling in year 2018 and year 2019

$31 \mathrm{~km}$ southwest of the Kalpin County (Fig. 1). Late Ordovician and Early Silurian rocks are well exposed in the Arisu section along a narrow and deep erosional stream- cut gorge. The Tierekeawati Formation disconformably overlies the Yingan Formation (Fig. 3). In the lower part of the Tierekeawati Formation, we have discovered red- 


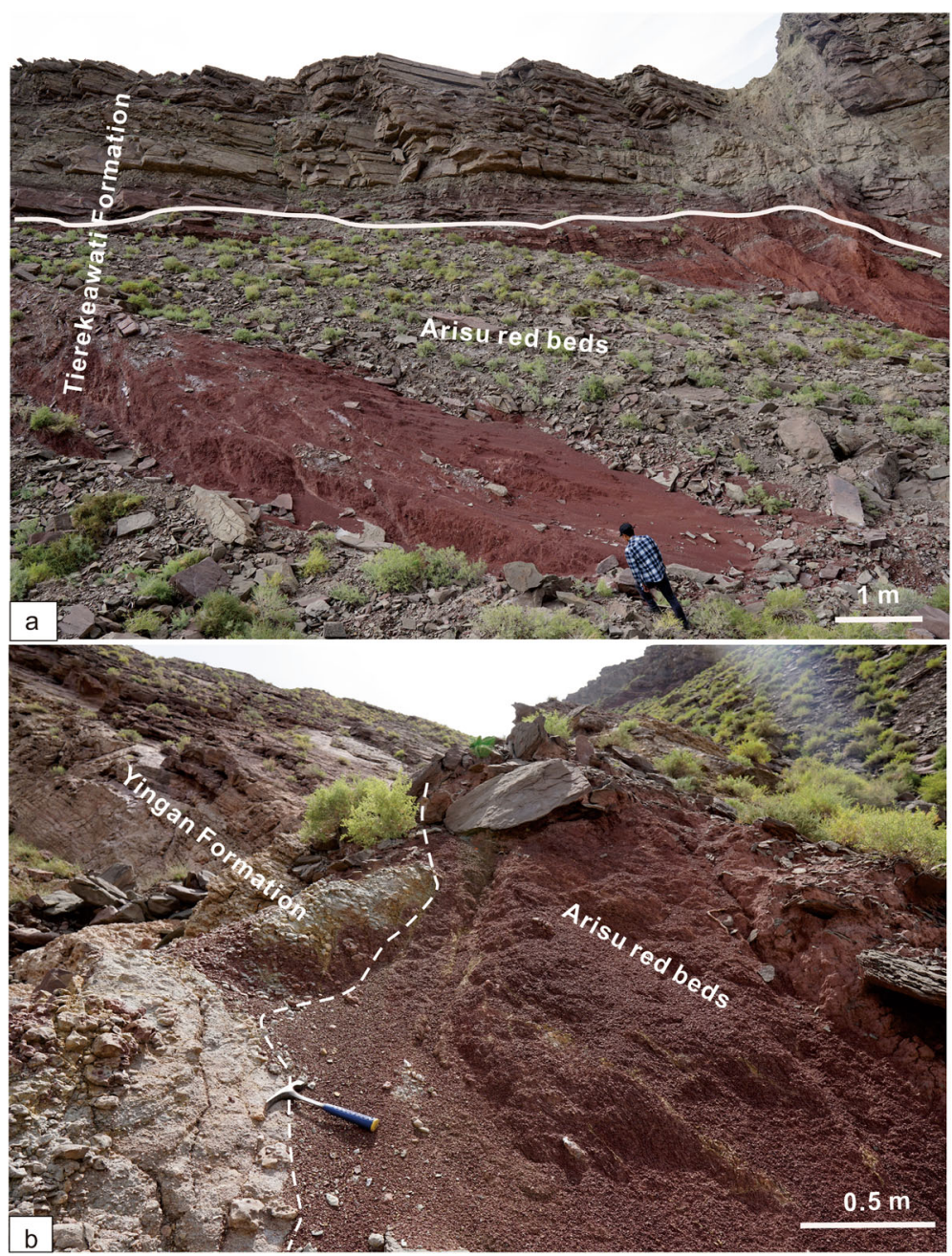

Fig. 3 a Field overview for the Arisu red beds of the lower Tierekeawati Formation; b Field photo shows the disconformity contact between the Yingan Formation and the Arisu red beds of the Tierekeawati Formation

coloured siliciclastic sediments comprising a mixture of shales, marls, siltstones and sandstones in the Kalpin area (Figs. 2 and 3), which varies from the previously described lithology of the Tierekeawati Formation. The red siliciclastics form a deposit about $34 \mathrm{~m}$ thick, composed of mainly purplish red mudstones intercalated with green to grey thin-bedded marlstones and grey thin- to medium-bedded sandstones at the top (Fig. 2). Trace fossils are common in the upper part of the deposit and ostracods are found in the lower part. In this study, the Arisu red beds is a temporary name for these redcoloured clastics of the lower Tierekeawati Formation, until a new lithostratigraphic unit is introduced in future work.

\section{Material and methods}

Thirty five samples, each about $1.5 \mathrm{~kg}$ in weight, were collected from the Arisu section (Figs. 1 and 2). For mudstones and siltstones, ostracods were extracted after dilute hydrogen peroxide $\left(\mathrm{H}_{2} \mathrm{O}_{2}\right)$ (15\%) processing. About 270 specimens were thus obtained from the Arisu section, mostly from fossiliferous sample 18XKR-02 in the lower part of the Arisu red beds (Fig. 2).

\section{Results}

The ostracod faunas obtained from the Arisu red beds of the Tierekeawati Formation are composed by Palaeocopida (e.g., Aparchitoidea, Drepanelloidea, Hollinoidea), Metacopida (e.g., Healdioidea, Longisculoidea, Thlipsuroidea), and Podocopida (e.g., Bairdioidea). In total 22 species belonging to 13 genera were recognized (Figs. 4 and 5). All specimens figured in this study are deposited in Nanjing Institute of Geology and Palaeontology, Chinese Academy of Sciences, and they are numbered from 171074 to 171101. 


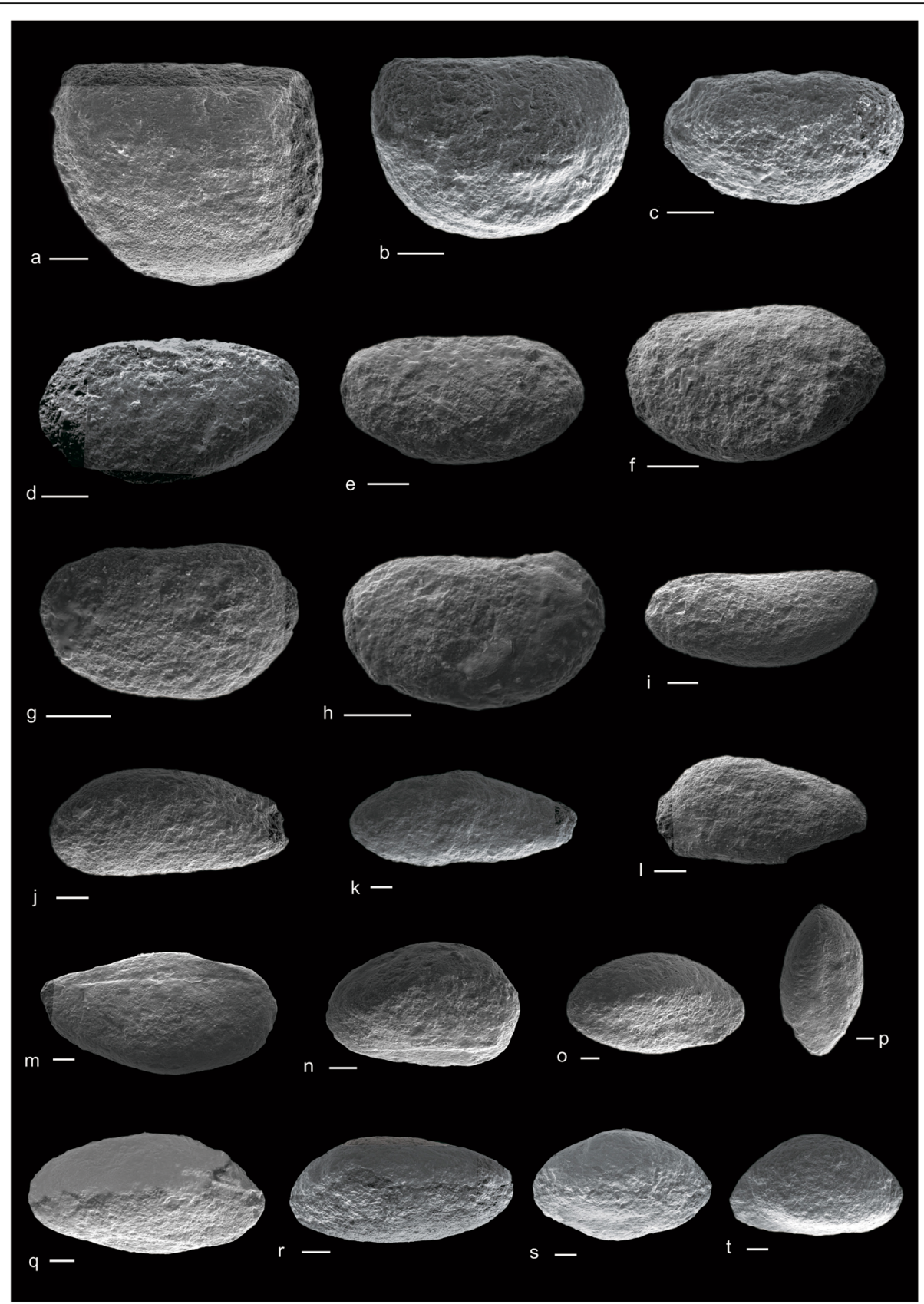

Fig. 4 Scanning electron micrographs of ostracods (I) from the Arisu red beds of the Tierekeawati Formation in Kalpin area, northwestern Tarim Basin, Northwest China. Scale bar is 100 um. a Aparchites sp. Right lateral view of complete carapace, 171074, Late Ordovician; b Paraeuprimitia cf. pulchra Sun, 1978 (Guan et al. 1978). Left lateral view of complete carapace, 171075, Late Ordovician; c Euprimitia cf. symmetrica (Hou 1956). Right lateral view of complete carapace, 171076, Late Ordovician; d Primitia monstrata Shi and Wang 1985. Right lateral view of complete carapace, 171077, Late Ordovician; e Primitia monstrata Shi and Wang 1985. Left lateral view of complete carapace, 171078, Late Ordovician; f Primitia cf. monstrata Shi and Wang 1985. Right lateral view of complete carapace, 171079, Late Ordovician; g Primitia cf. wangjiawanensis Sun, 1983 (Wang et al. 1983). Right lateral view of complete carapace, 171080, Late Ordovician; h Primitia cf. wangjiawanensis Sun, 1983 (Wang et al. 1983). Right lateral view of complete carapace, 171081, Late Ordovician; i Primitia sp. Right lateral view of complete carapace, 171082, Late Ordovician; j Predanwinula arguta Sun 1987. Right lateral view of complete carapace, 171083, Late Ordovician; k Predarwinula cf. arguta Sun 1987. Right lateral view of complete carapace, 171084, Late Ordovician; I Krausella sp. Left lateral view of complete carapace, 171085, Late Ordovician; m Krausella cf. calvini (Kay 1940). Right lateral view of complete carapace, 171086, Late Ordovician; n Nikitinella cf. pinnaformis Wang 2015. Right lateral view of complete carapace, 171087, Late Ordovician; o Longiscula cf. vulgaris Sun 1987. Right lateral view of complete carapace, 171088, Late Ordovician; p Longiscula cf. vulgaris Sun 1987. Dorsal view of complete carapace, 171089, Late Ordovician; q Longiscula subcylindrica (Ulrich 1889). Right lateral view of complete ca rapace, 171090, Late Ordovician; $\mathbf{r}$ Longiscula subcylindrica (Ulrich 1889). Left lateral view of complete carapace, 171091, Late Ordovician; s Fenxiangia rhombiformis Jiang, 1995 (Jiang et al. 1995). Right lateral view of complete carapace, 171092, Late Ordovician; t Fenxiangia rhombiformis Jiang, 1995 (Jiang et al. 1995). Right lateral view of complete carapace, 171093, Late Ordovician 


\section{Discussion}

\subsection{Age comparative analysis}

The ostracod assemblages from the Arisu red beds of the Tierekeawati Formation are characterized by Primitia, Predarwinula, Krausella, Longiscula, Fenxiangia, Euprimitia, Paraeuprimitia and Nikitinella, most of which are typical genera of the Ordovician. Primitia monstrata Shi and Wang 1985 (Fig. 4d-f) was first reported from the Upper Ordovician (Katian) Chedao Formation in Gansu Province, Northwest China (Shi and Wang 1985). Predarwinula arguta Sun 1987 (Fig. 4j) was originally described from the Upper Ordovician (Sandbian-Katian) Pagoda Formation in Hubei Province, South China (Sun 1987). Fenxiangia rhombiformis Jiang, 1995 (Jiang et al. 1995) (Fig. 4s, t) firstly appeared in the Upper Ordovician (Sandbian-Katian) 'Saergantag' Group in North Tarim Basin, Northwest China (Jiang et al. 1995). Longiscula subcylindrica (Ulrich 1889) (Fig. 4q, r) and Anticostus jolieti (Copeland 1973) (Fig. 5c) were discovered from the Upper Ordovician (late Katian) in Anticosti Island, East Canada (Taha 2018).
Moreover, most similar morphological species have been documented from the Upper Ordovician, for instance, Paraeuprimitia cf. pulchra Sun, 1978 (Guan et al. 1978) (Fig. 4b), Primitia cf. wangjiawanensis Sun, 1983 (Wang et al. 1983) (Fig. 4g, h) and Predarwinula cf. arguta Sun 1987 (Fig. 4k) discovered in the Upper Ordovician (Sandbian-Katian), Hubei Province, South China (Guan et al. 1978; Wang et al. 1983; Sun 1987) are similar to Paraeuprimitia pulchra, Primitia wangjiawanensis and Predarwinula arguta Sun 1987, respectively. Nikitinella cf. pinnaformis Wang 2015 (Fig. 4n) and Rectella? cf. proposita Abushik and Sarv 1983 (Fig. 5b) are similar to Nikitinella pinnaformis and Rectella? proposita Abushik and Sarv 1983 (Abushik and Sarv 1983) from the Upper Ordovician (Katian) in Zhejiang Province, South China (Wang 2015). Euprimitia cf. symmetrica (Hou 1956) (Fig. 4c) is similar to Euprimitia symmetrica (Hou 1956) from the Upper Ordovician (Sandbian-Katian) Yenwashan Formation in Jiangshan area, Zhejiang Province, South China (Hou 1956). Fenxiangia cf. puriformis Jiang, 1995 (Jiang et al. 1995) (Fig. 5a) is similar to

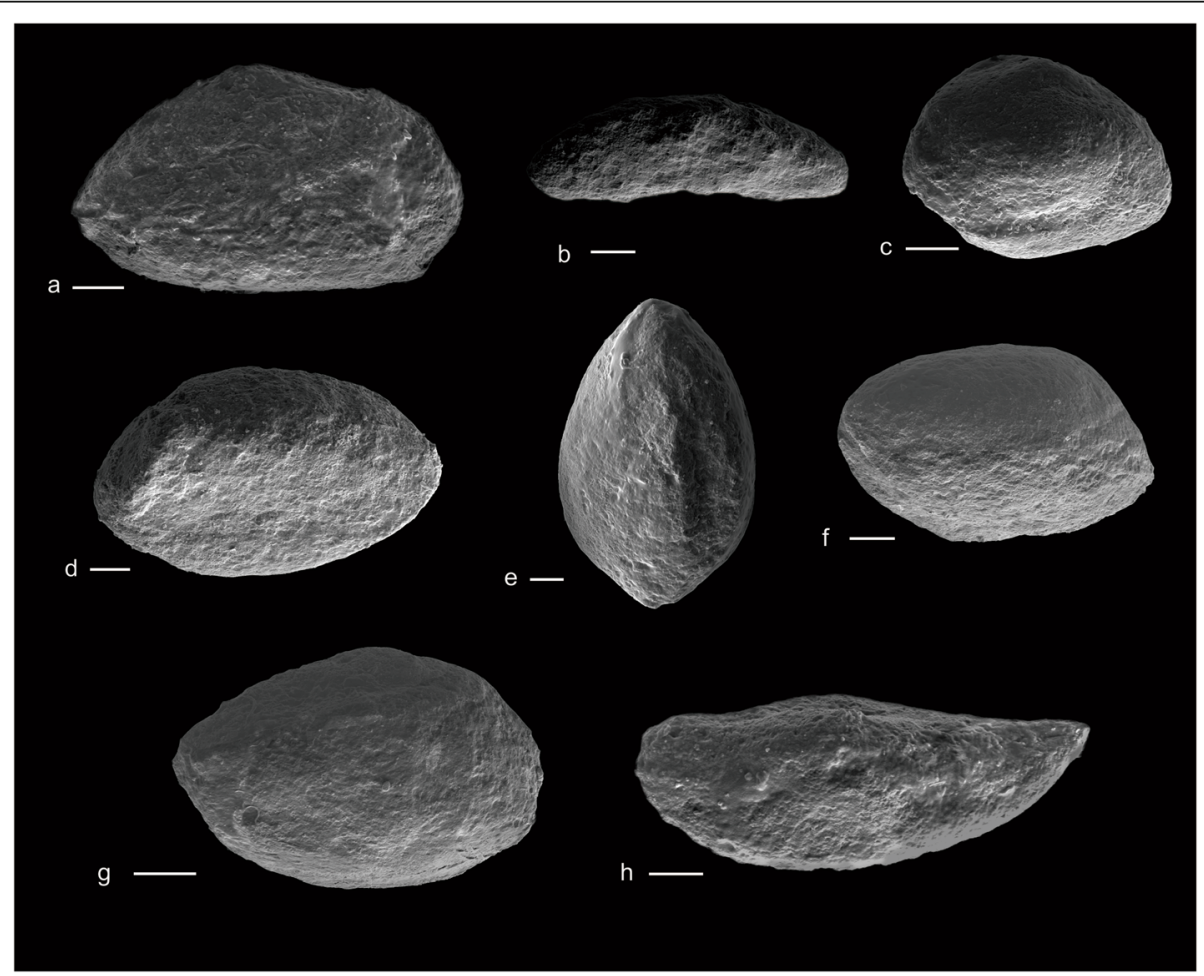

Fig. 5 Scanning electron micrographs of ostracods (II) from the Arisu red beds of the Tierekeawati Formation in Kalpin area, northwestern Tarim Basin, Northwest China. Scale bar is 100 um. a Fenxiangia of. puriformis Jiang, 1995 (Jiang et al. 1995). Left lateral view of complete carapace, 171094, Late Ordovician; b Rectella? cf. proposita Abushik and Sarv 1983. Left lateral view of complete carapace, 171095, Late Ordovician; c Anticostus jolieti (Copeland 1973). Left lateral view of complete carapace, 171096, Late Ordovician; d Bairdia cf. altitumida Wang 2015. Right lateral view of complete carapace, 171097, Late Ordovician; e Bairdia cf. altitumida Wang 2015. Dorsal view of complete carapace, 171098, Late Ordovician; f Bairdia cf. confragosa Jiang, 1995 (Jiang et al. 1995). Right lateral view of complete carapace, 171099, Late Ordovician; g Bairdia sp. Right lateral view of complete carapace, 171100, Late Ordovician; h Steusloffina cf. cuneata (Steusloff 1895). Left lateral view of complete carapace, 171101, Late Ordovician 
Fenxiangia puriformis from the Upper Ordovician (Sandbian-Katian) 'Saergantag' Group in North Tarim Basin, Northwest China (Jiang et al. 1995).

Overall, the age of ostracods from the Arisu red beds of the Tierekeawati Formation in this study is inferred as Sandbian-Katian Age.

\subsection{Palaeoenvironmental and palaeogeographical implications}

Detailed palaeoenvironmental studies of Ordovician ostracods are rare in general. Several researchers (e.g., Bandel and Beker 1975; Wang 1988) noted the cooccurring relationship between ostracod fauna and marine lithofacies of the Paleozoic. Two associations (i.e., Leperditella Association and Anisocyamus Association) were recognized from the Middle Ordovician Bromide Formation in southern Oklahoma area, America (Williams and Siveter 1996): the Leperditella Association was characterized by leperditiocope and some palaeocope (e.g., leiocope and eridostracan) ostracods and was restricted to lithofacies of very shallow or marginal marine environments; by contrast, the Anisocyamus Association was dominated by palaeocope, metacope, binodicope and podocope ostracods, occupying subtidally deposited marine sediments with wide geographical distribution from shallow to deeper marine. Five ostracod associations, i.e., the leperditiid, palaeocopid, smooth-podocopid, spinose-podocopid, and entomozoacean associations, were recognized in the Paleozoic strata of South China Plate by Wang (1988), which represent palaeoenvironments from nearshore to deep settings.

The ostracod fauna from the Arisu red beds of the Tierekeawati Formation is dominated by metacopids ( $\geq 50 \%$ of the total number of species), palaeocopids (about $32 \%$ of the total number of species), and podocopids ( $\leq 18 \%$ of the total number of species). Thus, the ostracod assemblage is similar to the Anisocyamus Association (Williams and Siveter 1996); and is also ecologically equivalent to the mixture of palaeocopid and smooth-podocopid associations (Wang 1988) and the Eifelian Ecotype (Bandel and Beker 1975), both of which are generally characterized by a rich and diverse ostracod fauna indicative of a nearshore-offshore setting (Bandel and Beker 1975; Wang 1988; Song and Gong 2019). In the middle part of the Arisu red beds, although body fossils are absent, trace fossils provide evidence for the palaeoenvironmental interpretation. Most of these trace fossils are Thalassinoides, Didymaulichnus, and Phycodes (Fig. 6a-c), and can imply a nearshore palaeoenvironment (Bromley 1996; Yang et al. 2004; Zhang and Gong 2013; Shahkarami et al. 2017). Moreover, small-scale cross-bedding and symmetrical ripples in the upper part of the Arisu red beds (Fig. 6d) also indicate nearshore shallow water. Overall, the Arisu red beds of the Tierekeawati Formation were deposited during a regressive process, in a nearshore-offshore depositional palaeoenvironment, followed by a shallowing-upward trend.

During Ordovician time, most of the Chinese terranes were located in or near the tropical areas in the northeastern peri-Gondwana region, including Tarim, South China, North China, Himalaya (South Tibet), Lhasa (North Tibet), and Sibumasu (Burrett et al. 1990; Metcalfe 2011; Zhan et al. 2016). Corals from the Upper Ordovician in Kalpin area, Northwest Tarim had a particularly close connection to the Late Ordovician faunas recorded in South China (Han et al. 2017). Similarly, three cephalopod provinces, the South China-TarimTibet-Sibumasu Province (STTS), the North China Province, and the Australia Province (Fang et al. 2019), were recognized for the Late Ordovician, which suggests close biogeographic relationships between the Tarim and South China Plates. Most ostracods from the Arisu red beds of the Tierekeawati Formation in Kalpin area, Northwest Tarim Basin are also similar to the Late Ordovician faunas recorded in South China. The Late Ordovician genera, which are common in Tarim Basin, such as Paraeuprimitia Sun, 1978 (Guan et al. 1978), Primitia Jones and Holl 1865, Nikitinella Melnikova 1986, Longiscula Neckaja 1958 and Fenxiangia Sun, 1978 (Guan et al. 1978), appeared simultaneously in Hubei and Zhejiang Provinces of South China (Guan et al. 1978; Wang et al. 1983; Sun 1987). Besides, Predarwinula arguta Sun 1987, firstly described from the Upper Ordovician in Hubei Province, South China (Sun 1987), is also recorded in the Upper Ordovician of southern Tibet Plate (Song et al. 2019), which might imply close biogeographic relations among Tarim, South China, and Tibet Plates during the Late Ordovician. Thus, we deduce that ostracods from Northwest Tarim, like other marine faunas such as corals (Han et al. 2017) and cephalopods (Fang et al. 2019), are similar to the Late Ordovician faunas recorded in South China and all belong to the STTS during the Late Ordovician. In addition, the ostracod fauna from Arisu red beds of the Tierekeawati Formation in Tarim Basin, belonging to the STTS, can be geo-ecologically compared to the faunas of Europe and North America continents during the Late Ordovician. For instance, Steusloffina cuneata (Steusloff 1895) also in the Upper Ordovician of Southwest Scotland (Mohibullah et al. 2011); Krausella calvini (Kay 1940) was first discovered in the Late Ordovician Decorah Formation of Iowa area (Kay 1940), and common in the Middle Ordovician Bromide Formation of Oklahoma area, America (Williams and Siveter 1996); Anticostus jolieti (Copeland 1973) also appeared from the Late Ordovician (late Katian) Ellis Bay Formation in 

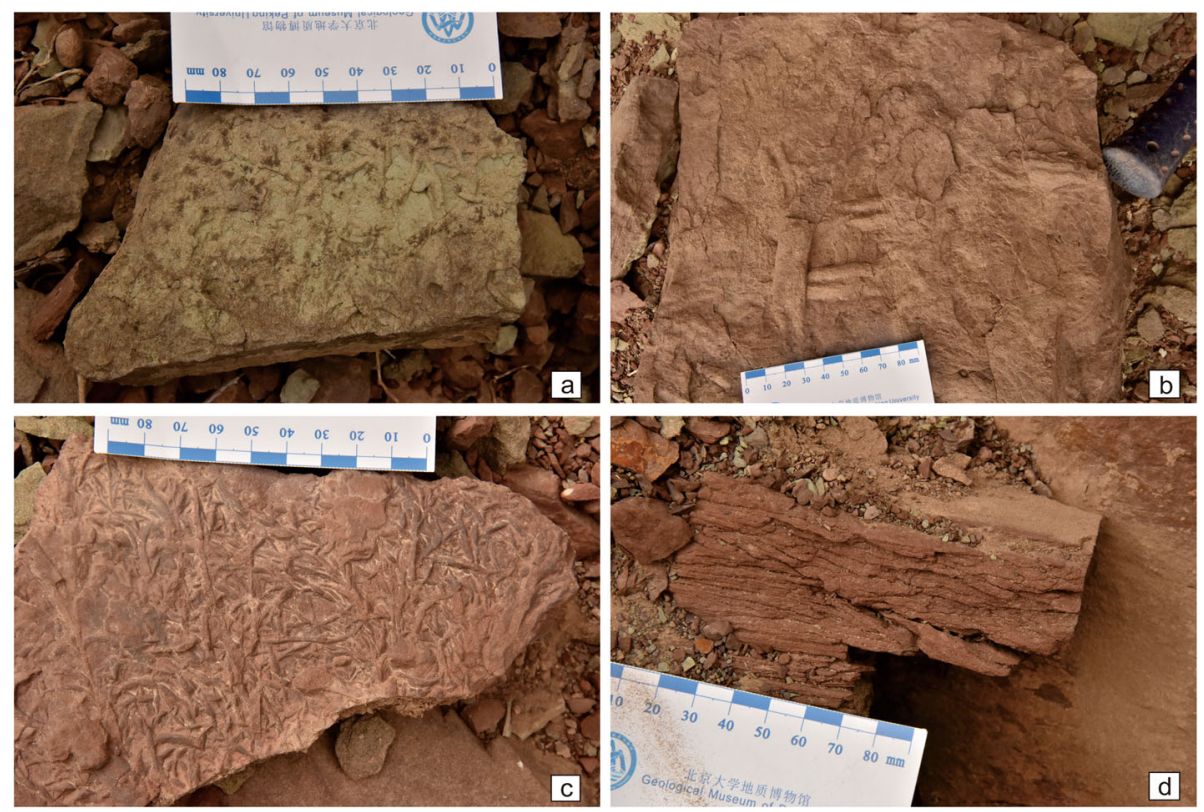

Fig. 6 Field photos of trace fossils (a-c) and sedimentary structure (d) in the Arisu red beds of the Tierekeawati Formation in Kalpin area, northwestern Tarim Basin, Northwest China. a Thalassinoides; b Didymaulichnus; c Phycodes; d Small-sized cross-bedding in the upper part of the Arisu red beds

eastern Canada. These findings demonstrate that ostracods experienced faunal exchanges between Laurentia and the Tarim Plate during the Late Ordovician.

\section{Conclusions}

1) Twenty-two species belonging to thirteen ostracod genera are described and figured for the first time from the red-coloured marine sandstones of Arisu section (Arisu red beds) of the Upper Ordovician Tierekeawati Formation in Kalpin area, northwestern Tarim Basin, Northwest China.

2) The ostracod fauna suggests a probable SandbianKatian age for the Arisu red beds, and implies that the Arisu red beds were deposited in a regressive nearshore-offshore palaeoenvironment followed by a shallowing-upward trend.

3) Ostracod faunas of the Arisu red beds are diversified with many global and/or regional genera, suggesting these ostracods belonging to the South China-Tarim-Tibet-Sibumasu Province (STTS) during the Late Ordovician, same as corals and cephalopods.

4) The ecological assemblage of ostracods in the Arisu red beds is similar to the Anisocyamus Association and also corresponds to the Eifelian Ecotype.

5) It is inferred that there were possible biogeographic relationships among Tarim, Tibet, and South China Plates, as well as Europe and North America continents during the Late Ordovician Period.

\section{Abbreviations}

GOBE: Great Ordovician Biodiversification Event; STTS: South China-TarimTibet-Sibumasu Province

\section{Acknowledgements}

The authors sincerely thank Dr. Ruo-Ying Fan from China University of Geosciences (Wuhan) for her warm-hearted assistances in the identification of trace fossils. Prof. Stephen Kershaw from Brunel University London is also sincerely acknowledged for his constructive comments and professional suggestions, which greatly improved the quality of this article.

\section{Authors' contributions}

JJS and YXS conceived the idea of this study and composed the manuscript. PT, XLZ, QJL and ZJL discussed the results and revised the manuscript. The authors read and approved the final manuscript.

\section{Funding}

This work was financially supported by the National Natural Science Foundation of China (Grant Nos. 41802002, 41872035 and 41702003), and Strategic Priority Research Program (B) of Chinese Academy of Sciences (Grant No. XDB26000000).

\section{Availability of data and materials}

The datasets used during the current study are available from the corresponding author on reasonable request.

\section{Competing interests}

The authors declare that they have no competing interests.

\section{Author details}

${ }^{1}$ Nanjing Institute of Geology and Palaeontology, Chinese Academy of Sciences, Nanjing 210008, Jiangsu Province, China. ${ }^{2}$ Center for Excellence in Life and Paleoenvironment, Chinese Academy of Sciences, Nanjing 210008, Jiangsu Province, China. ${ }^{3}$ College of Geoscience and Technology, China University of Petroleum (East China), Qingdao 266580, Shandong Province, China. ${ }^{4}$ State Key Laboratory of Palaeobiology and Stratigraphy, Nanjing Institute of Geology and Palaeontology, Chinese Academy of Sciences, Nanjing 210008, Jiangsu Province, China. ${ }^{5}$ PetroChina Xinjiang Oilfield 
Company, Research Institute of Experiment and Detection, Karamay 834000, Xinjiang Uygur Autonomous Region, China.

\section{Received: 20 December 2019 Accepted: 6 May 2020 Published online: 29 May 2020}

\section{References}

Abushik, A., and L. Sarv. 1983. Ostracody Molodovskgo Gorizonta Podolii. In: Klaamann, E. (Ed.). Paleontologiya Drevnego Paleozoya Pribaltiki i Podolii. Akademiya Nauk Estonskoy SSR, Tallin, pp. 101-134.

Bandel, K., and G. Beker. 1975. Ostracoden aus paläozoischen pelagischen Kalken der Karnischen Alpen (Silurium bis Unterkarbon). Senckenbergiana Lethaea 56: 1-84.

Bromley, R.G. 1996. Trace fossils_Biology, Taphonomy and applications. 2nd ed, 361. London: Chapman\&Hall.

Burrett, C., J. Long, and B. Stait. 1990. Early-middle Palaeozoic biogeography of Asian terranes derived from Gondwana. In Palaeozoic biogeography and palaeogeography, Geological society of London memoir, ed. W.S. McKerrow and C.R. Scotese, vol. 12, 163-174.

Chen, X., S.M. Bergström, Y.D. Zhang, and Z.H. Wang. 2013. A regional tectonic event of Katian (late Ordovician) age across three major blocks of China. Chinese Science Bulletin 58: 4292-4299.

Chen, X., Y.D. Zhang, Y. Li, J.X. Fan, P. Tang, Q. Chen, and Y.Y. Zhang. 2012. Biostratigraphic correlation of the Ordovician black shales in Tarim Basin and its peripheral regions. Science China Earth Sciences 55: 1230-1237.

Copeland, M.J. 1973. Ostracoda from the Ellis Bay formation (Ordovician), Anticosti Island, Quebec. Geological Survey of Canada Paper 72: 1-48.

Fang, X., C. Burrett, W.J. Li, Y.B. Zhan, Y.D. Zhang, T.G. Chen, and X.J. Wu. 2019. Dynamic variation of middle to late Ordovician cephalopod provincialism in the northeastern peri-Gondwana region and its implications. Palaeogeography, Palaeoclimatology, Palaeoecology 521: 127-137.

Frey, R.C., M.S. Beresi, D.H. Evans, A.H. King, and I.G. Percival. 2004. Nautiloid cephalopods. In The great Ordovician biodiversification event, ed. D.B. Webby, F. Paris, M.L. Droser, and I.G. Percival, 209-213. New York: Columbia University Press.

Guan, S.Z., Q.Y. Sun, Y.W. Jiang, L.L. Li, B.Q. Zhao, X.Q. Zhang, R.L. Yang, and B.Y. Feng. 1978. Palaeontological atlas of Central China Micropalaeontology volumes - Ostracods, 115-324. Beijing: Geological Publishing House (in Chinese with English abstract).

Han, X.M., X.Y. Zhang, B.Z. Yang, J.G. Sun, F.Q. Zhou, P.F. Zhao, and Q.T. Wang. 2017. Discovery and geological significance of the coral fossils of Yingan formation in Keping, Xinjiang. Geological Science and Technology Information 36: 13-19 (in Chinese with English abstract).

Horne, D.J., A. Cohen, and K. Martens. 2002. Taxonomy, morphology and biology of quaternary and living Ostracoda. In The Ostracoda: Applications in quaternary research, ed. J.A. Holmes and A.R. Chivas, 5-36. Washington, D.C.: American Geophysical Union.

Hou, Y.T. 1956. The Ordovician ostracods from western Chekiang. Acto Palaeontologica Sinica 4: 535-597 (in Chinese with English abstract).

Huang, Z.B., S.H. Deng, P.D. Du, S.B. Zhang, Z.J. Tan, Y.Z. Lu, Z.L. Yang, B.Q. Dong, X.M. Yang, and X.C. Jing. 2009. New progress in the research of Ordovician stratigraphy of Tarim Basin. In Proceedings of memorializing 20 years for petroleum Battle in Tarim oilfield (exploration volume), ed. X.Y. Zhou and Z.M. Wang, 172-186. Beijing: Petroleum Industry Press (in Chinese with English abstract).

Jia, C.Z., S.B. Zhang, and S.Z. Wu. 2004. Stratigraphy of the Tarim Basin and adjacent areas, volume II, 516. Beijing: Science Press (in Chinese).

Jiang, X.T., W.F. Zhou, and S.P. Lin. 1995. Stratigraphy and Ostracode fossils of Xinjiang, 577. Beijing: Geological Publishing House (in Chinese).

Jones, T.R., and H.B. Holl. 1865. Notes on the Palaeozoic bivalved Entomostraca - 8: Some lower-Silurian. Annals and Magazine of Natural History Series 3 16: 414-425.

Kay, G.M. 1940. Ordovician Mohawkian ostracoda: Lower Trenton Decorah fauna. Journal of Paleontology 14: 234-269.

Landing, E., M. Mohibullah, and M. Williams. 2013. First middle Ordovician ostracods from Western Avalonia: Paleogeographical and
Paleoenvironmental significance Avalonian early middle Ordovician ostracods. Journal of Paleontology 87: 269-276.

Li, Q.J., Y. Li, Y.Y. Zhang, and A. Munnecke. 2017. Dissecting Calathiummicrobial frameworks: The significance of calathids for the middle Ordovician reefs in the Tarim Basin, northwestern China Palaeogeography, Palaeoclimatology, Palaeoecology 474: 66-78.

Melnikova, L.M. 1986. Ordoviskie Ostrakody Kazakhstana. Trudy Paleontologicheskogo Instituta Akademii Nauk SSSR 218: 1-104.

Metcalfe, I. 2011. Palaeozoic-Mesozoic history of SE Asia. In The SE Asian gateway: History and tectonics of the Australia-Asia collision, ed. R. Hall, M.A. Cottam, and M.E.J. Wilson, vol. 355, 7-35. London: Geological Society Special Publications.

Mohibullah, M., T.R.A. Vandenbroucke, and M. Williams. 2011. Late Ordovician (Sandbian) ostracods from the Ardwell farm formation Southwest Scotland. Scottish Journal of Geology 47: 57-66.

Neckaja, A.l. 1958. Novye Rody i Vidy Ostrakod Ordovika i Silura SeveroZapada Russkoy Platformy. Trudy Vsesoyuznogo Neftyanogo NauchnoIssledovatelskogo Geologo Razvedchnogo Instituta (Vnigri). Novaya Seriya 115: 349-379.

Qiao, X.D. 1986. Graptolite zone of the Ordovician and early Silurian in Kalpin region, Xinjiang. Xinjiang Geology 4: 53-59 (in Chinese with English abstract).

Salas, M.J. 2011. Early Ordovician (Floian) ostracods from the cordillera oriental, Northwest Argentina. Geological Journal 46: 637-650.

Shahkarami, S., M.G. Mángano, and L.A. Buatois. 2017. Discriminating ecological and evolutionary controls during the Ediacaran-Cambrian transition: Trace fossils from the Soltanieh formation of northern Iran. Palaeogeography, Palaeoclimatology, Palaeoecology 476: 15-27.

Shi, C.G., and D.H. Wang. 1985. Middle Ordovician ostracodes from Huanxian, Gansu. Bullentin of Xi' An Institute of Geology and Mineral Resources, Chinese Academy of Geological Sciences 10: 95-104 (in Chinese with English abstract).

Siveter, D.J. 2008. Ostracods in the Palaeozoic. Senckenbergiana Lethaea 88 $1-9$

Song, J.J., and Y.M. Gong. 2019. Ostracods from the Devonian-carboniferous transition in Dushan of Guizhou, South China. Palaeobiodiversity and Palaeoenvironments 99: 117-127.

Song, J.J., W. Guo, W.K. Qie, Y.C. Zhang, J.Y. Huang, and Y.J. Wang. 2019. Late Ordovician ostracods in Nyalam, southern Tibet. Acta Palaeontologica Sinica 58 (3): 296-310 (in Chinese with English abstract).

Steusloff, A. 1895. Neue Ostracoden aus Diluvial Geschiben von Neubrandenburg. Zeitschrift der Deutschen Geologischen Gesellschaft 46: 775-787.

Sun, Q.Y. 1987. Ostracoda/biostratigraphy in the Yangtze gores (2). In Early Paleozoic, 335-363. Beijing: Geological Publishing House (in Chinese).

Swain, F.M. 1957. Early middle Ordovician Ostracoda of the eastern United States. Part I. stratigraphic data and description of Leperditiidae, Aparchitidae and Leperditellidae. Journal of Paleontology 31: 528-570.

Taha, Z.A. 2018. The taxonomic, biogeographical, Palaeogeographical and Palaeoecological significance of the late Ordovician ostracod Fauna of the Ellis Bay formation, Anticosti Island, eastern CanadaThesis submitted for the degree of Doctor of Philosophy at the University of Leicester, 182.

Tang, P., X.Y. Cai, and Y. Liang. 2012. Chitinozoans of late Ordovicianearly Silurian in Kalpin area of northwestern Tarim Basin. In Abstracts of the $9^{\text {th }}$ China Microfossil Congress and the $14^{\text {th }}$ Conference-the $7^{\text {th }}$ China Fossil Algae Congress and the $15^{\text {th }}$ Conference, Tengchong, Yunnan, 40-41 (in Chinese).

Tinn, O., and T. Meidla. 2002. An enigmatic early ?Palaeocope ostracode from the Arenig of NW Russia. Acta Palaeontologica Polonica 47: 685-690.

Ulrich, E.O. 1889. On some Polyzoa (Bryozoa) and Ostracoda from the Cambro-Silurian rocks of Manitoba. Geological Survey of Canada Contributions to the micropalaeontology of the Cambro-Silurian rocks of Canada 2: 27-57.

Wang, S.Q. 1988. Late Paleozoic ostracode associations from South China and their paleoecological significance. Acta Palaeontologica Sinica 27: 91-102 (in Chinese with English abstract). 
Wang, S.Q. 2015. Ordovician and Silurian Ostracoda of China, 272. Hefei: University of Science and Technology of China Press (in Chinese).

Wang, X.F., Q.L. Zeng, T.M. Zhou, S.Z. Ni, G.H. Xu, Q.Y. Sun, Z.H. Li, L.W. Xiang, and C.G. Lai. 1983. Latest Ordovician and earliest Silurian faunas from the eastern Yangtze gorges, China with comments on OrdovicianSilurian boundary. Bulletin of Yichang Institute of Geology and Mineral Resources, Chinese Academy of Geological Sciences 6: 95-163 (in Chinese with English abstract).

Wang, Z.H., Y.P. Qi, and S.M. Bergström. 2007. Ordovician conodonts of the Tarim region, Xinjiang, China: Occurrence and use as palaeoenvironment indicators. Journal of Asian Earth Sciences 29: 832-843.

Williams, M., J.D. Floyd, M.J. Salas, D.J. Siveter, P. Stone, and J.M.C. Vannier. 2003. Patterns of ostracod migration for the 'North Atlantic' region during the Ordovician. Palaeogeography, Palaeoclimatology, Palaeoecology 195: 193-228.

Williams, M., and D.J. Siveter. 1996. Lithofacies-influenced ostracod associations in the middle Ordovician bromide formation, Oklahoma, USA. Journal of Micropalaeontology 15: 69-81.

Wu, T. 2003. Ostracodes from the Ordovician of northern Tarim Basin, Xinjiang. Acta Micropalaeontologica Sinica 20: 318-324 (in Chinese with English abstract).

Yang, S.P., J.P. Zhang, and M.F. Yang. 2004. Trace fossils of China, 353. Beijing: Science Press (in Chinese).

Zhan, R.B., J.S. Jin, J.B. Liu, P. Corcoran, X.C. Luan, and X. Wei. 2016. Meganodular limestone of the pagoda formation: A time-specific carbonate facies in the upper Ordovician of South China. Palaeogeography, Palaeoclimatology, Palaeoecology 448: 349-362.

Zhang, K., A.H. Yuan, and Q.L. Feng. 2018. The upper Ordovician microfossil assemblages from the pagoda formation in Zigui, Hubei Province. Journal of Earth Science 29: 900-911.

Zhang, L.J., and Y.M. Gong. 2013. Ichnocoenosis of the lower Devonian Pingyipu formation, Longmen Mountain, Sichuan. Acta Palaeontologica Sinica 52: 86-95 (in Chinese with English abstract).

Zhang, Y.D., and A. Munnecke. 2016. Ordovician stable carbon isotope stratigraphy in the Tarim Basin, NW China. Palaeogeography, Palaeoclimatology, Palaeoecology 458: 154-175.

Zhang, Y.D., R.B. Zhan, Y.Y. Zhen, Z.H. Wang, W.W. Yuan, X. Fang, X. Ma, and J.P. Zhang. 2019. Ordovician integrative stratigraphy and timescale of China. Science China Earth Sciences 62: 61-88.

Zhao, Z.X., G.Z. Zhang, and J.N. Xiao. 2000. Paleozoic stratigraphy and conodonts in Xinjiang, 340. Beijing: Petroleum Industry Press (in Chinese).

Zhen, Y.Y., Z.H. Wang, Y.D. Zhang, S.M. Bergström, I.G. Percival, and J.F. Cheng. 2011. Middle to late Ordovician (Darriwilian-Sandbian) conodonts from the Dawangou section, Kalpin area of the Tarim Basin, northwestern China. Records of the Australian Museum 63: 203-266.

Zhou, Z.Y. 2001. Stratigraphy of the Tarim Basin, 359. Beijing: Science Press (in Chinese).

Zhou, Z.Y., and P.J. Chen. 1992. Biostratigraphy and geological evolution of Tarim, 399. Beijing: Science Press (in Chinese).

Zhou, Z.Y., X. Chen, Z.H. Wang, Z.Z. Wang, J. Li, L.Y. Geng, Z.J. Fang, X.D. Qiao, and T.R. Zhang. 1992. Ordovician of Tarim. In Biostratigraphy and geological evolution of Tarim, ed. Z.Y. Zhou and P.-J. Chen, 62-139. Beijing: Science Press (in Chinese with English abstract).

\section{Publisher's Note}

Springer Nature remains neutral with regard to jurisdictional claims in published maps and institutional affiliations.

\section{Submit your manuscript to a SpringerOpen ${ }^{\circ}$ journal and benefit from:}

- Convenient online submission

Rigorous peer review

- Open access: articles freely available online

- High visibility within the field

- Retaining the copyright to your article

Submit your next manuscript at $\boldsymbol{\nabla}$ springeropen.com 